\title{
Orbital time scale records of Asian eolian dust from the Sea of Japan since the early Pliocene
}

\author{
Wenfang Zhang ${ }^{\text {a, * }}$, David De Vleeschouwer ${ }^{b}$, Ji Shen ${ }^{a,{ }^{*}}$, Zeke Zhang ${ }^{c}$, Lin Zeng ${ }^{\mathrm{d}}$ \\ a State Key Laboratory of Lake Science and Environment, Nanjing Institute of Geography and Limnology, Chinese Academy of Sciences, Nanjing 210008, \\ China \\ ${ }^{\mathrm{b}}$ MARUM - Center for Marine Environmental Sciences, University of Bremen, Bremen, Germany \\ ${ }^{\mathrm{c}}$ Institute of Earth Environment, Chinese Academy of Sciences, Xi'an 710075, China \\ ${ }^{\mathrm{d}}$ Key Laboratory of Coastal Environmental Processes and Ecological Remediation, Yantai Institute of Coastal Zone Research, Chinese Academy of Sciences, \\ Yantai, China
}

\section{A R T I C L E I N F O}

\section{Article history:}

Received 23 October 2017

Received in revised form

1 February 2018

Accepted 5 March 2018

Available online 30 March 2018

\section{Keywords:}

Sea of Japan

IODP site U1422

Asian dust

Pliocene

Pleistocene

\begin{abstract}
A B S T R A C T
A high-resolution potassium content record of sediments from Integrated Ocean Drilling Program (IODP) Site U1422 drilled in the northern Sea of Japan was employed to yield an astronomical timescale for this $\sim 205 \mathrm{~m}$ thick sedimentary archive. The $\mathrm{K}$ content was quantified using the natural gamma radiation (NGR) data routinely measured on DV JOIDES Resolution. The U1422 K (wt.\%) series shows an increasing trend with time, which parallels the growth of North Hemisphere ice sheets since $4 \mathrm{Ma}$, as revealed by the global benthic foraminifer's oxygen isotope stack (LR04). We propose that K content variations reflect changes in the relative contributions of Asian eolian dust and volcanic weathering products, in response to changes in global ice volume. Using the shipboard age model, constrained by palaeomagnetism and nanofossils datums, we tuned the U1422 K content variations to the LR04 stack. Our tuned age model for site U1422 goes back to 3.9 Ma. The studied record indicates that Asian dust generation is enhanced during periods of global cooling. The synchronous variations between the U1422 K record and the LR04 stack also suggest that global cooling played a dominant role in promoting the central Asian aridification since $3.9 \mathrm{Ma}$, while the uplift of Tibetan Plateau plays a secondary role, considering many disagreements still exists between the timing and amplitude of the Qinghai-Tibetan uplift and the evolution of central Asian aridity since the early Pliocene.
\end{abstract}

(c) 2018 Elsevier Ltd. All rights reserved.

\section{Introduction}

The central Asian interior is the second largest dust emission center all over the word (Engelbrecht and Derbyshire, 2010). Once launched into the atmosphere, Asian dust is then transported to a proximal accumulation center, the Chinese Loess Plateau (CLP), or distal accumulation center, e.g. the Sea of Japan, or the north Pacific Ocean via high-altitude westerly winds and/or near surface East Asian Winter Monsoon (EAWM) (Shao et al., 2011; Sun et al., 2001). Asian dust flux archived in the CLP and north Pacific sediments has

\footnotetext{
* Corresponding author. State Key Laboratory of Lake Science and Environment, Nanjing Institute of Geography and Limnology, Chinese Academy of Sciences, 73 East Beijing Road, Nanjing 210008, China.

** Corresponding author.

E-mail addresses: wfzhang@niglas.ac.cn (W. Zhang), jishen@niglas.ac.cn (J. Shen).
}

been suggested as a robust indicator of aridity in Asian interior (Hovan et al., 1989; Rea et al., 1998; Sun and An, 2005; Zhang et al., 2016). Three factors, i.e. global cooling (Lu and Guo, 2013), uplift of Tibetan Plateau (An et al., 2001) and retreat of the Paratethys Sea (Ramstein et al., 1997), have been suggested as potential drivers for the stepwise development of aridity in Central Asia during the late Cenozoic. However, the most important factor controlling the aridification of Central Asia is still highly debated (e.g. Miao et al., 2012).

A long-term increase in eolian flux since 3.6 Ma has been observed on the CLP (Sun and An, 2005), in the north central Pacific ocean (Rea et al., 1998), Arabian Sea (Clemens et al., 1996), equatorial Atlantic ocean (Tiedemann et al., 1994) as well as Southern ocean (Martinez-Garcia et al., 2011). These eolian flux records are interpreted to reflect the past aridity of source regions, which has been dynamically linked to the development of Northern Hemisphere ice sheet since the late Pliocene. The progressive increase of 
benthic $\delta^{18} \mathrm{O}$ since the late Pliocene marked the onset of Northern Hemispheric Glaciation and progressive global cooling (De Vleeschouwer et al., 2017b; Lisiecki and Raymo, 2005). Global cooling could reduce the amount of water vapor held in the atmosphere and thus be the cause of aridity in the central Asian interior (Lu and Guo, 2013). However, the sudden drying at 3.6 Ma revealed by the low-resolution eolian dust accumulation record at ODP site 885/886 from north central Pacific ocean was attributed to the uplift of the north Tibetan Plateau, which blocked the input moisture from the Indian Ocean to the interior of continental Asia (Rea et al., 1998). A high-resolution Asian dust record in the North Pacific Ocean would be helpful to constrain the exact controlling mechanism of aridity in the Asian interior. However, the average sedimentation rates of Asian dust in the CLP, the Sea of Japan as well as north Pacific oceans over the past 50,000 years show an exponential decreasing trend along the eastward transportation of Asian dust (Zhang et al., 2016). The slow deposition rate of sediments in north central Pacific Ocean would possibly prevent high-resolution magnetic reversal stratigraphy (Janecek and Rea, 1983; Rea et al., 1993, 1998). This in turn prevents achieving the high eolian flux in north central Pacific sediments.

The Sea of Japan is located in the downwind pathway of Asian dust transportation, which mainly receives eolian dust from the central Asian interior, such as Mongolian Gobi desert and Taklimakan Desert (Nagashima et al., 2007). A high-resolution record of clay minerals assemblages in the Sea of Japan indicated a drying history of the central Asia interior since 3.5 Ma (Shen et al., 2017). This history is consistent with the eolian record from North China, the South China Sea and the North Pacific Ocean, as well as aridity reconstructions from the northern Tibetan Plateau (Shen et al., 2017). But a high-resolution orbital timescale eolian dust record has not been conducted in the Sea of Japan, impeding our understanding of interactions between Asian aridity and global cooling.

The generation of accurate age models of the eolian dust-bearing sediments could help to reliably reconstruct the eolian dust flux through time. Tuning monsoon-driven proxy records to periodic variations in the Earth's orbital parameters has been successfully applied to reconstruct the chronology of different paleoclimate archives (Ding et al., 2002; Sun et al., 2006; Yu and Ding, 1998). For example, Sun et al. (2006) used the magnetic susceptibility and grain size records from the CLP to generate an improved astronomical timescale for the loess-palaeosol sequence and extended the age model to the upper red-clay formation. Ao et al. (2011) tuned the hematite/goethite ratio, a good proxy for the Asian summer monsoon intensity, to the $65^{\circ} \mathrm{N}$ summer insolation, helping to refine the timescale of IODP Site 1143 drilled in the southern South China Sea. In addition, the eolian dust component could also be a link between the loess records and pelagic sediments in north Pacific ocean to tie the Chinese loess-soil sequence directly to the benthic $\delta^{18} \mathrm{O}$ time scale (Hovan et al., 1989). The good temporal synchronicity between eolian dust records from the Subarctic north Pacific and north Greenland ice core (Serno et al., 2015) supports the reliability of the proposed dust tuning method and suggested it can be used more widely in other ocean basins.

Here, we present an orbital timescale for the Asian dust record of the 205-m-long sedimentary archive of IODP site U1422C drilled in the Sea of Japan, using the K (wt.\%) content. We quantified the $\mathrm{K}$ content of U1422C sediments, applying the MATLAB algorithm of De Vleeschouwer et al. (2017a) to natural gamma radiation (NGR) spectra. These spectra were routinely measured on the ocean drilling research vessel, DV JOIDES Resolution, during IODP Expedition 346 in the Sea of Japan (De Vleeschouwer et al., 2017a; Expedition 346 Scientists, 2014). We propose that the U1422C K record reflects changes in the relative contribution of windblown Asian dust from the central Asian interior and volcanic ash since the early Pliocene. Subsequently, we tuned the U1422C K (wt.\%) content record to the stacked 57 globally distributed benthic $\delta^{18} \mathrm{O}$ records (LR04 stack) (Lisiecki and Raymo, 2005), providing a highresolution age control for the site, back to $\sim 3.9$ Ma. We further employ the U1422C K record to discuss the variability of Asian dust as well as the aridity history throughout the last 2.9 Ma on glacialinterglacial, as well as on longer time scales. We report a positive correlation between the K contents of U1422 sediments and the stacked oxygen isotope, suggesting that global cooling played a dominant role in promoting the aridity of central Asian interior since the early Pliocene.

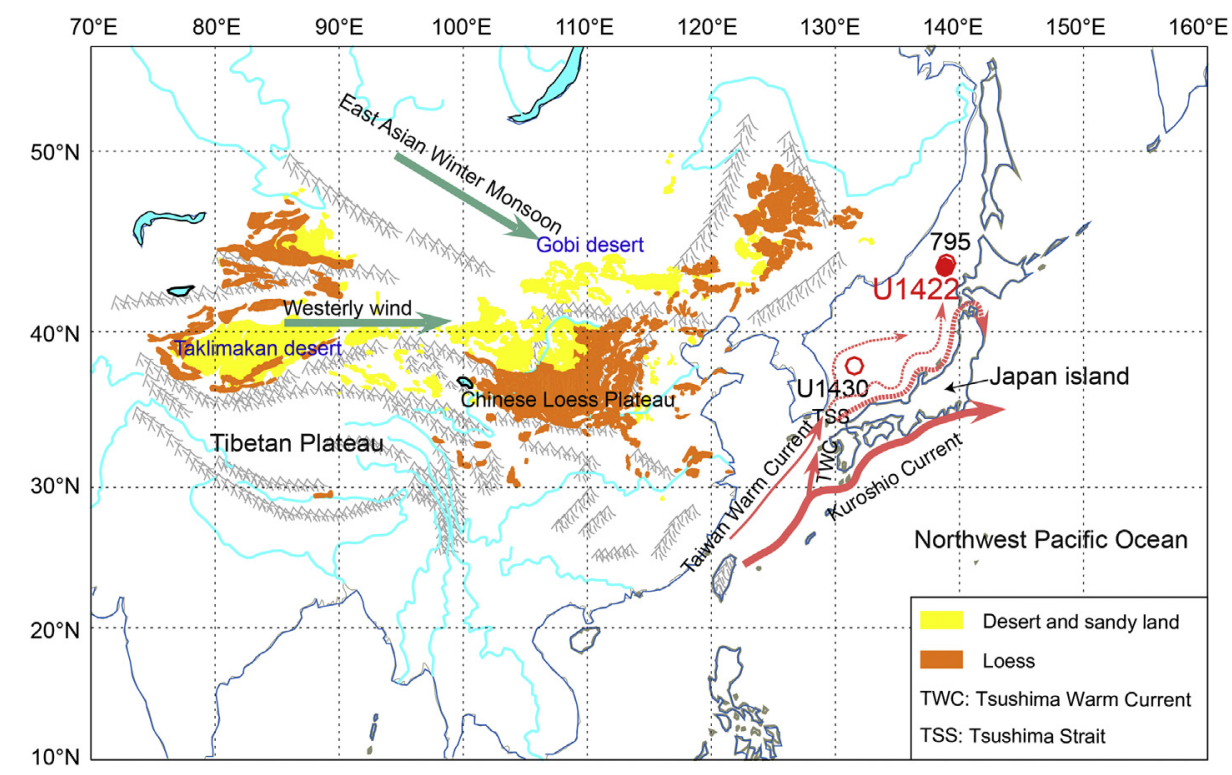

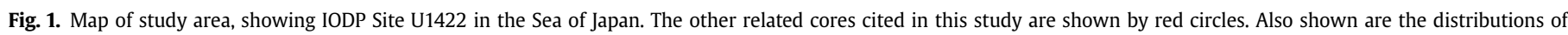

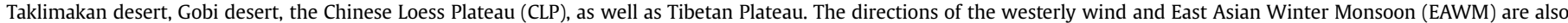

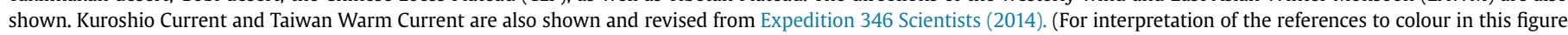
legend, the reader is referred to the Web version of this article.) 

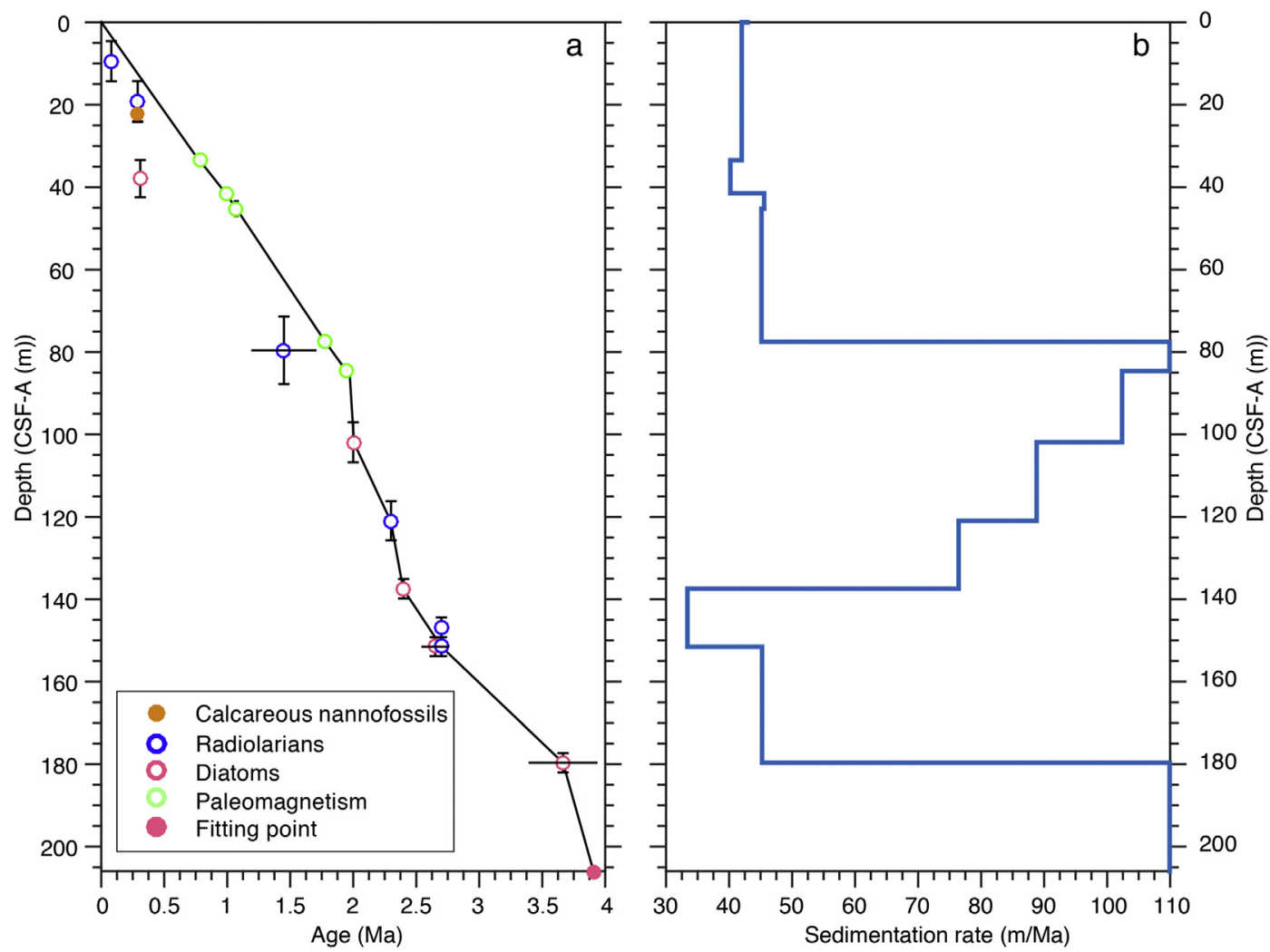

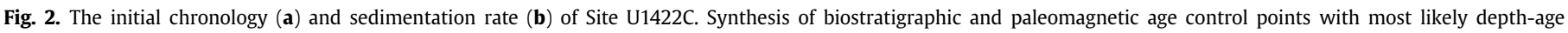
relationship lines to establish a preliminary age model. The biostratigraphic and paleomagnetic age data are from Expedition 346 Scientists (2014).

\section{Geological setting and materials}

IODP Site U1422 $\left(43^{\circ} 45.99^{\prime} \mathrm{N}, 138^{\circ} 49.99^{\prime} \mathrm{E}, 3429\right.$ m water depth $)$ was drilled in the northeastern part of Sea of Japan between the
Eurasian continent and the Japanese Islands (Fig. 1). Site U1422 is the northernmost site of the latitudinal transect targeted by IODP Expedition 346 and is also the deepest site of the depth transect (Expedition 346 Scientists, 2014). Five holes were cored at Site

Table 1

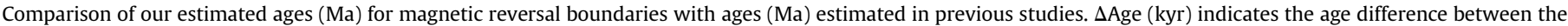
S1995 age model and the age model at the midpoint of these boundaries depth intervals in this study.

\begin{tabular}{|c|c|c|c|c|c|c|c|}
\hline Magnetic reversal boundaries & Depth (m, CSF-A) & Depth Uncertainty (m) & Age (our age model) & Age interval (our age model) & C1995 & S1995 & $\Delta$ Age \\
\hline $\mathrm{B} / \mathrm{M}$ & 33.5 & 0.83 & 0.819 & $0.783-0.843$ & 0.78 & 0.78 & 39 \\
\hline $\mathrm{TJ}$ & 41.5 & 0.3 & 0.991 & $0.985-0.996$ & 0.99 & 0.99 & 1 \\
\hline BJ & 45.2 & 1.8 & 1.076 & $1.035-1.127$ & 1.07 & 1.07 & 6 \\
\hline TO & 77.5 & 1.27 & 1.779 & $1.758-1.819$ & 1.77 & 1.77 & 9 \\
\hline $\mathrm{BO}$ & 84.6 & 0.6 & 1.952 & $1.934-1.965$ & 1.95 & 1.95 & 2 \\
\hline
\end{tabular}

C1995: Cande and Kent (1995); S1995: Shackleton (1995). B/M=Brunhes/Matuyama; TJ = Top Jaramillo; BJ=Bottom Jaramillo; TO=Top Olduvai; BO=Bottom Olduvai.

Table 2

Comparison of our estimated ages (Ma) for Microfossils bio-events with ages (Ma) estimated in preliminary report (Expedition 346 Scientists, 2014).

\begin{tabular}{|c|c|c|c|c|c|}
\hline Bio-event type & Bioevents and epoch boundaries & Age (Ma) (preliminary report) & Midpoint (depth, m, CSF-A) & Depth interval (m, CSF-A) & Age interval (our age model) \\
\hline $\mathrm{R}$ & LO Amphimelissa setosa & 0.08 & 9.44 & $4.59-14.29$ & $0.087-0.317$ \\
\hline $\mathrm{R}$ & LO Spongodiscus sp. & 0.29 & 19.14 & $14.28-24$ & $0.317-0.530$ \\
\hline $\mathrm{CN}$ & FO Emiliania huxleyi & 0.29 & 22.22 & $20.25-24.19$ & $0.459-0.534$ \\
\hline $\mathrm{D}$ & LO Proboscia curvirostris & 0.31 & 37.94 & $33.4-42.48$ & $0.815-1.009$ \\
\hline $\mathrm{R}$ & LO Axoprunum acquilonium & $1.2-1.7$ & 79.58 & $71.38-87.78$ & $1.637-1.995$ \\
\hline $\mathrm{D}$ & LO Neodenticula koizumii & 2 & 101.9 & $97-106.8$ & $2.115-2.231$ \\
\hline $\mathrm{R}$ & LO Cycladophora sakaii & 2.3 & 120.94 & $116.18-125.7$ & $2.380-2.498$ \\
\hline $\mathrm{D}$ & FO Neodenticula seminae & 2.4 & 137.42 & $135.07-139.77$ & $2.666-2.737$ \\
\hline $\mathrm{R}$ & FO Cycladophora davisiana & 2.7 & 146.8 & $144.41-149.19$ & $2.820-2.902$ \\
\hline $\mathrm{D}$ & LO Neodenticula kamtschatica & $2.6-2.7$ & 151.51 & $149.19-153.83$ & $2.902-2.976$ \\
\hline $\mathrm{R}$ & LO Hexacontium parviakitaensis & 2.7 & 151.51 & $149.19-153.83$ & $2.902-2.976$ \\
\hline $\mathrm{D}$ & FO Neodenticula koizumii & $3.40-3.93$ & 179.65 & $177.33-181.97$ & $3.234-3.315$ \\
\hline
\end{tabular}

$\mathrm{R}=$ radiolarian, $\mathrm{CN}=$ calcareous nanofossil, $\mathrm{D}=$ diatom, $\mathrm{LO}=$ last occurrence, $\mathrm{FO}=$ first occurrence. 
U1422 using the advanced piston corer and nonmagnetic core barrels. In Hole U1422C, drilling penetrated to a maximum subbottom depth of $205 \mathrm{~m}$ (depth below seafloor, CSF-A). The lithology of the recovered core is dominated by clay, silty clay, and diatomaceous clay with minor volcaniclastic material. The minerals in the sediment at Site U1422C are composed mainly of quartz, plagioclase, and clay minerals, including illite, smectite, and kaolinite and/or chlorite, as well as biogenic opal-A and minor amounts of halite and pyrite (Expedition 346 Scientists, 2014).

A rough initiated age model of site U1422C was established using five paleomagnetism age points after 2 Ma and biostratigraphic datums (calcareous nannofossils, diatom and radiolarians) prior to 2 Ma (Expedition 346 Scientists, 2014) (Fig. 2). The Brunhes/Matuyama (B/M) boundary $(0.78 \mathrm{Ma})$ was identified at $\sim 33.5 \mathrm{~m}$ (CSF-A). The top of the Olduvai Chron, a short interval with relatively stable positive inclinations around the expected dipole inclination value are identified between $\sim 41.5 \mathrm{~m}$ and $45.2 \mathrm{~m}$ CSF-A and was interpreted as the Jaramillo Subchron (0.988-1.072 Ma). The top of the Olduvai Chron (C2n, $1.778 \mathrm{Ma}$ ) was observed at 77.5 m CSF-A. The bottom of the Olduvai Subchron (C2n, $1.945 \mathrm{Ma}$ ) was recorded at $\sim 84.6 \mathrm{~m}$ (CSF-A) (Table 1). Below the interpreted bottom of the Olduvai Chron, strong overprint and the lack of orientation for the bottom cores, as well as the large scatter in declination makes reliable magneto-stratigraphic interpretations difficult (Expedition 346 Scientists, 2014). Microfossils bio-events are generally based on analysis of core catcher and split-core section samples from Hole U1422C. The age, depth and uncertainties of these microfossils bio-events are summarized in Table 2. Planktonic and benthic foraminifers are also examined in core catcher samples. However, planktonic foraminifers could not be used to help generate the biostratigraphy model, as index markers were mainly reworked. Abundance of benthic foraminifers is generally low, and preservation varies significantly, preventing them to be used to generate the biostratigraphy model (Expedition 346 Scientists, 2014).

We quantified $\mathrm{K}$ contents (wt.\%) of U1422C sediments by applying the MATLAB algorithm of De Vleeschouwer et al. (2017a) to the $20 \mathrm{~cm}$ spaced NGR spectra available for that hole (Fig. 3a; Supplementary Table 1). The NGR system installed on DV JOIDES Resolution measures the intensity of gamma radiation at 1024 different channels, or energy levels, between 0 and $3000 \mathrm{keV}$ (Vasiliev et al., 2011). The NGR intensity measured at an energy

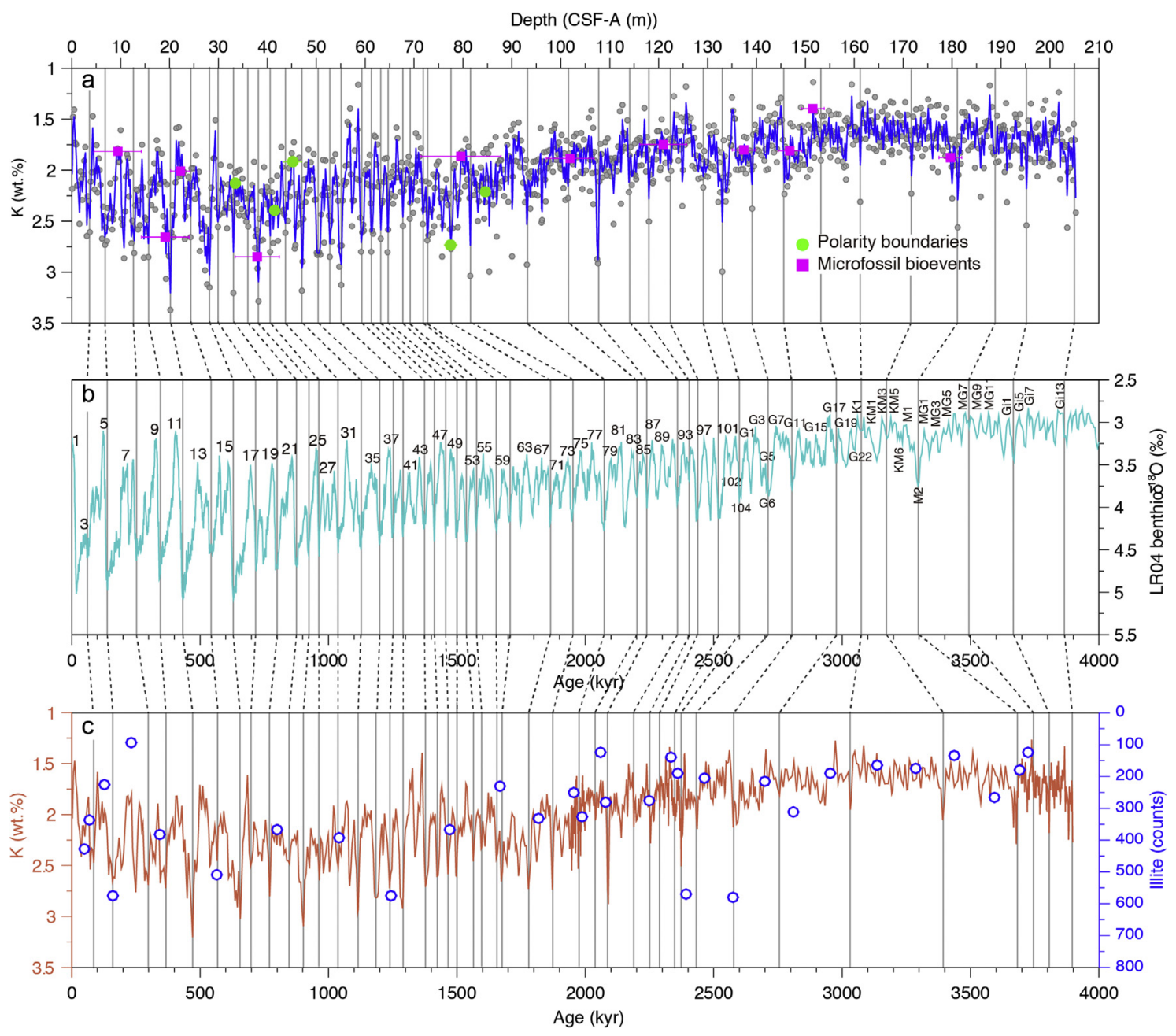

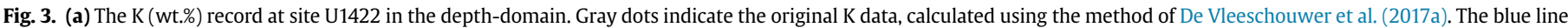

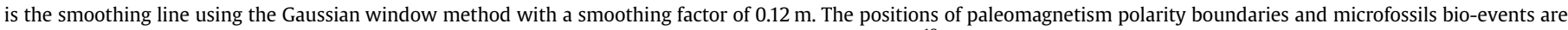

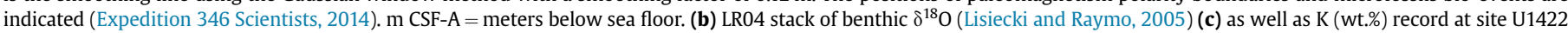

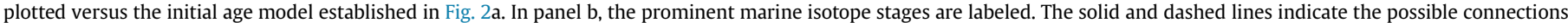

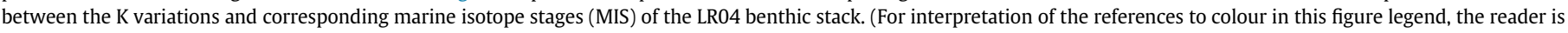
referred to the Web version of this article.) 
level characteristic for $\mathrm{K}, \mathrm{U}$, or Th is proportional to the content of that element in the sediment. Thus, the NGR data measured on shipboard allows for an estimation of the $\mathrm{K}, \mathrm{U}$, and Th contents from the shipboard NGR energy spectra (De Vleeschouwer et al., 2017a; Dunlea et al., 2013; Gilmore, 2011). A comparison of the algorithm's results with ICP-ES, ICP-MS, and XRF measurements of the element contents of $\mathrm{K}, \mathrm{U}$, and Th demonstrates the accuracy of the algorithm estimates, with satisfactory precision and accuracy (De Vleeschouwer et al., 2017a).

The original $\mathrm{K}$ data are smoothed by a Gaussian filter with standard deviation of the Gaussian window of $0.12 \mathrm{~m}$ (Fig. 3a; Supplementary Table 1). Morlet wavelet analysis is applied to evaluate the imprint of astronomical forcing in the $\mathrm{K}$ time-series (after tuning) (Torrence and Compo, 1998). As wavelet analysis requires equally-sampled data, we applied linear interpolation to a $1 \mathrm{kyr}$ spaced grid to the time series. Wavelet coherence is conducted and applied to examine the coherence and phase relationship of the coherence between our $\mathrm{K}$ record and ice volume (Grinsted et al., 2004).

\section{Proxy indicators of aridity in Asian interior}

The $\mathrm{K}$ component of the natural gamma ray log is often an indication of the concentration of K-bearing aluminosilicates, mainly clays and feldspar (Ehrenberg and Svånå, 2001). The variations of XRD peak intensity of identified minerals that are illite, smectite, K-feldspar and quartz from the preliminary report, show a generally increasing trend from the bottom to top. The covariation of illite with $\mathrm{K}$ data (Fig. 3c) implies that the amount of illite mimeral would be the dominant factor controlling the variations of $\mathrm{K}$ content at Site U1422C. The overall increasing illite has also been observed at site U1430, just south of Site U1422 (Expedition 346 Scientists, 2014; Shen et al., 2017) (Fig. 4e). The variations of these minerals implied a gradual increasing contribution of Asian dust since the late Pliocene in the Sea of Japan. The sediments materials in the Sea of Japan show two end-members mixture, with one end-member being Asian dust that originates from the central Asian interior and is transported by westerly wind and/or EAWM, while the other end-member consists of volcanic ash or its alternation materials eroded from the Japan island by fluvial systems (Nagashima et al., 2013; Shen et al., 2017). The Asian dust is enriched in illite and poor in smectite, whereas, the Japan volcanoes are characterized by high content of smectite and lower illite (Shen et al., 2005, 2017). These interpretations are strengthened by the variations of $\mathrm{Nd}$ and $\mathrm{Sr}$ isotopes from Site U1430 sediments since about late Pliocene. $\mathrm{Nd}$ and $\mathrm{Sr}$ isotopes also identified two end-members mixture of eolian dust from Central Asia and fluvial input from Japan for the sediments in the Sea of Japan. Asian end-member supplied high ${ }^{87} \mathrm{Sr} /{ }^{86} \mathrm{Sr}$ and low $\varepsilon_{\mathrm{Nd}}(0)$ eolian dust by westly wind and/or EAWM, while Japanese end-member which is characterized with young volcanic rocks, contributed low ${ }^{87} \mathrm{Sr} /{ }^{86} \mathrm{Sr}$ and high $\varepsilon_{\mathrm{Nd}}(0)$ weathering products via rivers. The low-resolution $\varepsilon_{\mathrm{Nd}}(0)$ shows a generally negative trend since $\sim 3.6 \mathrm{Ma}$, indicating an increase of eolian input and a stepwise drying of Central Asia (Shen et al., 2017).

We interpret variations in the concentration of $\mathrm{K}(\mathrm{wt} . \%)$ at site U1422C as reflecting relative contribution of windblown Asian dust emitted from the central Asian interior and volcanic weathering products since the Pliocene. We propose the $K$ (wt.\%) variations as a proxy of Asian aridity of the central Asian interior. The Asian eolian dust archived in the sediment from north Pacific ocean and the Sea of Japan generally has a median diameter of less than $8 \mu \mathrm{m}$ after a long transportation (Janecek, 1985; Janecek and Rea, 1983, 1985; Jeong et al., 2014; Zhang et al., 2016). This fine particle mainly consists of clay minerals, followed by small amount of quartz,

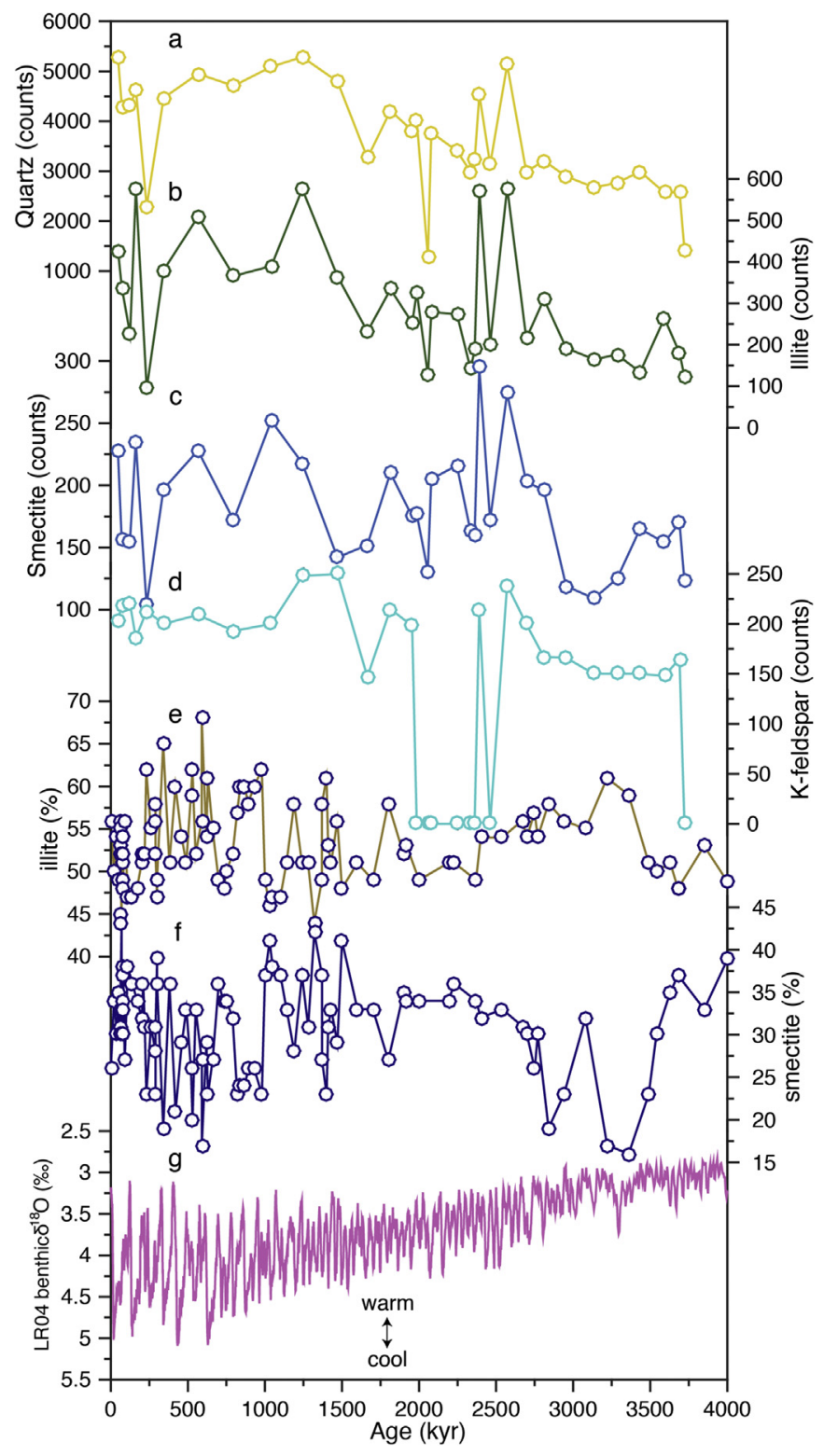

Fig. 4. Variation of XRD peak intensity of identified minerals, quartz (a), illite (b), smectite (c), k-feldspar (d) with the age established in Fig. 2a, IODP site U1422C. The minerals data are from Expedition 346 Scientists (2014). Also shown is illite at site $\mathrm{U} 1430(\mathbf{e})$, smectite at site $\mathrm{U} 1430(\mathbf{f})$, as well as LR04 stack of benthic $\delta^{18} \mathrm{O}(\mathbf{g})$ (Lisiecki and Raymo, 2005). The illite and smectite data at Site U1430 are from Shen et al. (2017).

plagioclase, K-feldspar, and calcite. It has been shown that the fine fractions are enriched in micas and clays while the quartz and feldspars tend to be concentrated in the coarse fractions in dust deposits through the effect of mineral sorting during transport (Pye, 1987). This is supported by the aerosols collected above the Asian source regions which are enriched in clay minerals such as illite, smectite and chlorite and are depleted quartz and feldspars in the $<5 \mu \mathrm{m}$ fraction (Ferrat et al., 2011; Kanayama et al., 2005).

The potential contributions of Korean rivers, Yangtze, Yellow and Taiwan rivers sediments may also influence the $\mathrm{K}$ variations of sediments at site U1422C in the Sea of Japan. These sediments could be transported to the central Sea of Japan by the Tsushima Warm Current (TWC), a branch of the Kuroshio Current, the only current flowing into the Sea of Japan through the Tsushima Strait (Fig. 1). However, clay mineralogy and $\mathrm{Sr}$, $\mathrm{Nd}$ and $\mathrm{Pb}$ isotopes evidence in 


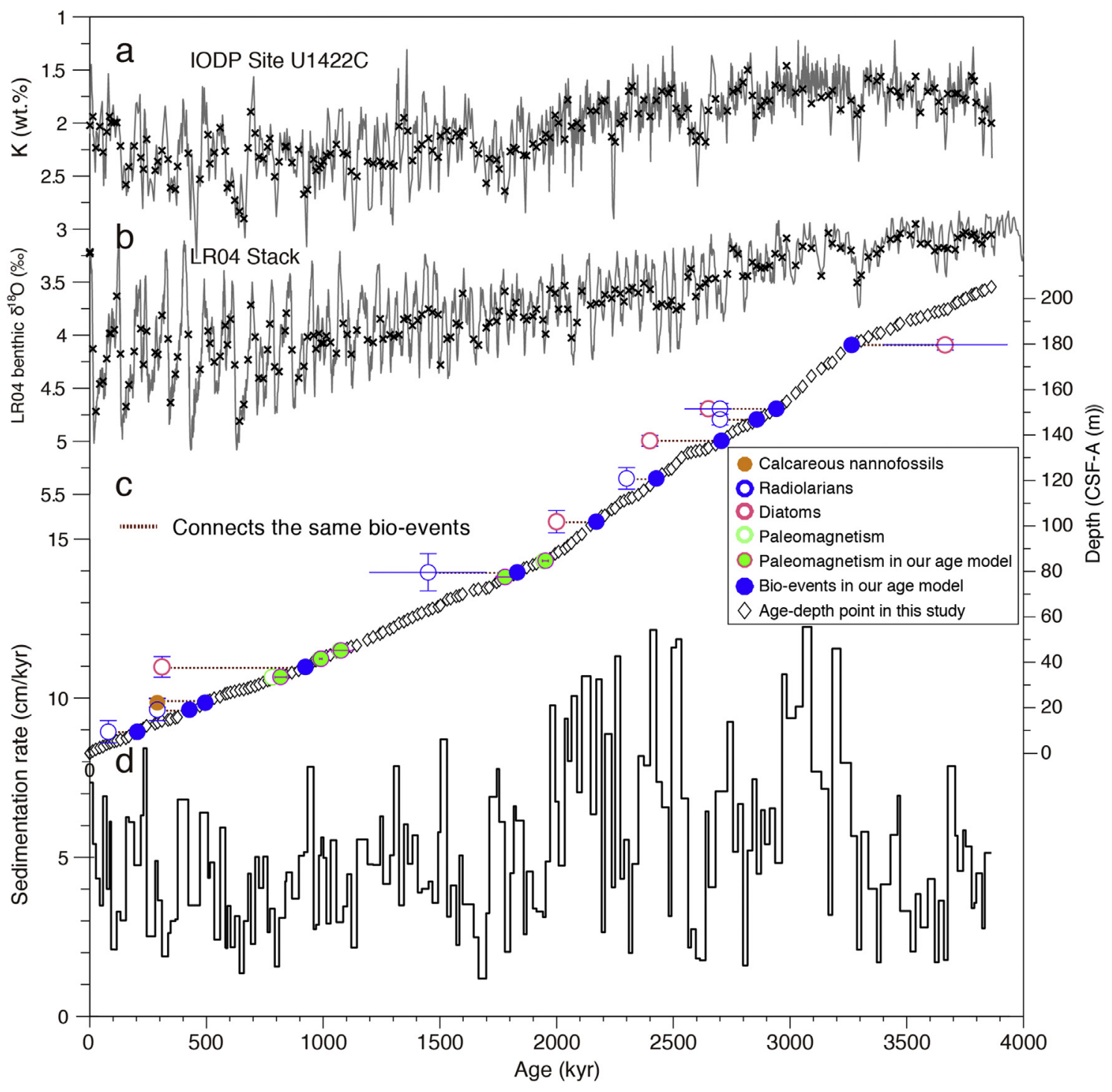

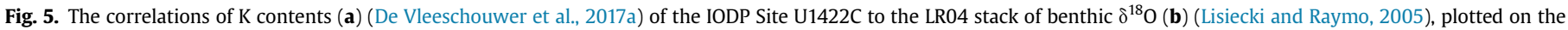
LR04 age model, with sedimentation rates for the tuning solution (c).

recent study unambiguously excluded the significant contributions from these end-members, because of the obvious deviation of these rivers samples from the mixing lines of the potential sources, i.e. Asian dust and volcanic ash (Shen et al., 2017). Site U1422 is moreover located in the northernmost of the Sea of Japan, which make significant contributions from these rivers sediments even more unlikely (Fig. 1).

The relatively different characteristics of minerals in source deserts in Asian interior might be another factor influencing the variations of $\mathrm{K}$ data at site U1422C. Taklimakan desert and Mongolian Gobi desert are generally considered to be the main source areas for the long-range transportation of Asian dust (Nagashima et al., 2007) (Fig. 1). The temporal changes in the provenance of sediments in the Sea of Japan exhibit variations on millennial timescale to multimillennial-scale, with dominance of Gobi dust in stadials as a result of the southward move of westerly wind and the dominance of Taklimakan dust in inter-stadials when the EAWM was less strong (Nagashima et al., 2011). We argue that the bias introduced by the fluctuations of different source materials could not be the significant drivers for the $\mathrm{K}$ variations. The slight overlapping of aerosols mineral compositions collected during these two deserts was observed (Shen et al., 2005). The clay mineral compositions of Asian dust from different source areas in the Asian interior exhibit the relative coherency when compared with that of volcanic ash, with Asian dust end-member supplying richer illite and volcanic rocks end-member contributing richer smectite (Shen et al., 2017).

Another possible factor controlling $\mathrm{K}$ content is chemical weathering in the source regions, which possibly complicates interpretation of $\mathrm{K}$ content as a proxy of Asian aridity of the central Asian interior. The interpretation of $\mathrm{K}$ content as reflecting relative contribution of windblown Asian dust from the central Asian interior in Site U1422 sediments assumes that the central Asian interior and volcanic rocks supplied steady illite and smectite minerals compositions since the early Pliocene, respectively. However, the mineral compositions in dust source and volcanic rocks might vary following the evolving weathering intensity in response to the global cooling since the early Pliocene and periodic paleoclimatic change during glacial and inter-glacials cycles (Lisiecki and Raymo, 2005). Illite is generally formed under cold and 


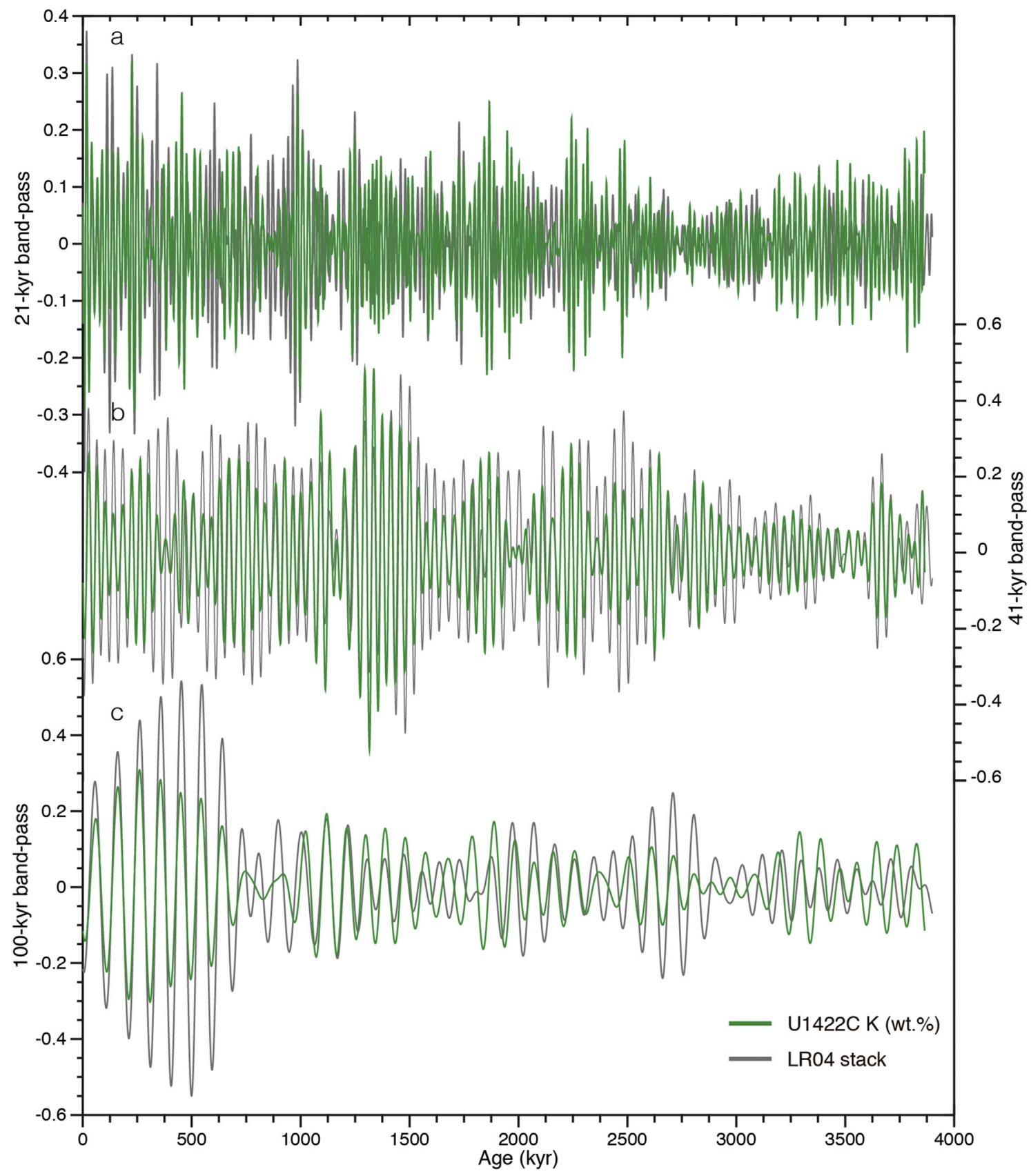

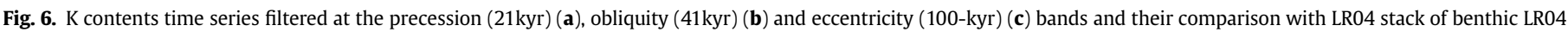

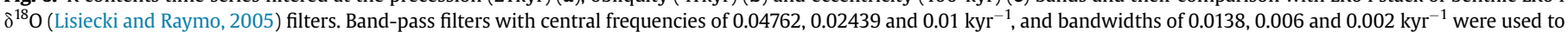
isolate the 21,41 , and $100 \mathrm{kyr}$ components of the $\mathrm{K}$ content time series.

arid climate conditions (Chamley, 1989), while smectite is often produced under the condition of the rapid chemical weathering of volcanic rocks in wet and humid environments (Biscaye, 1965). Thus, the high $\mathrm{K}$ contents as reflected by more illite and less smectite during glacial might be attributable to the increase of illite as a result of the chemical weathering other than the increased aridity. Resolving the role of aridity and chemical weathering on the illite content is difficult. We could not exclude this factor, as clay mineral compositions in dust source regions do not yet have high resolution record. We propose that the aridity might be the dominant factor controlling the variations of illite, as the intensity of chemical weathering during glacial might be weak, producing less clay (illite) minerals. The glacial dust fluxes in north Pacific oceans is about a factor of 2.5 higher than the interglacial fluxes, which is generally suggested to be drived by the aridity in dust source regions (Hovan et al., 1989; Winckler et al., 2008). Nevertheless, we propose that the $\mathrm{K}$ content retrieved from U1422C sediments would reflect the relative contribution of Asian dust input from the Asian interior and could be accepted as an indicator of aridification in the Asian interior.

\section{Calibration and evaluation of the astronomical timescale}

Our tuning strategy starts from the assumption that the aridity of central Asian interior depends to a large degree on global ice volume. This assumption has proven to be valid, and several studies 


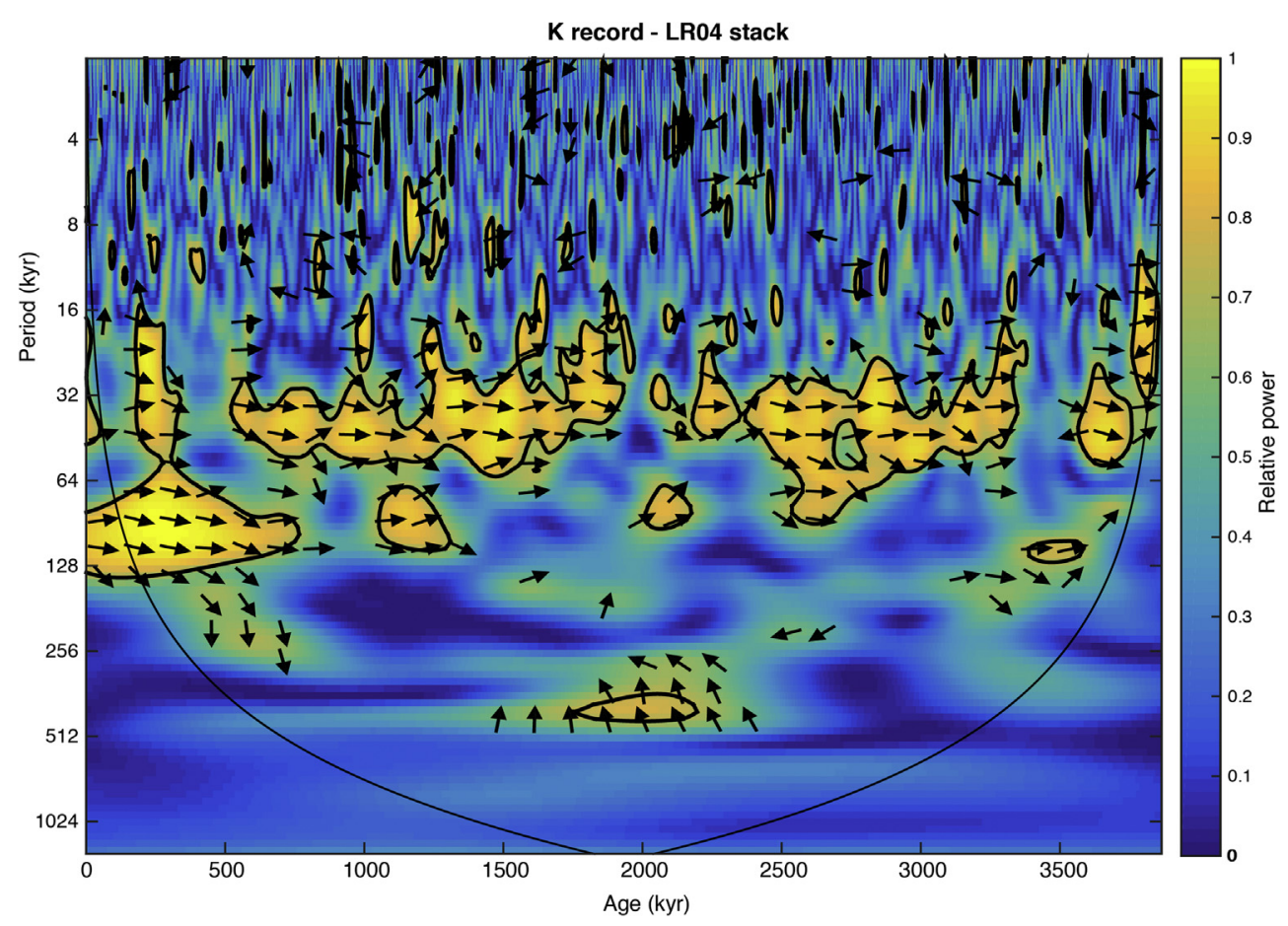

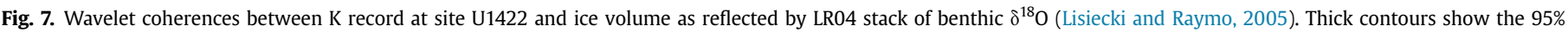

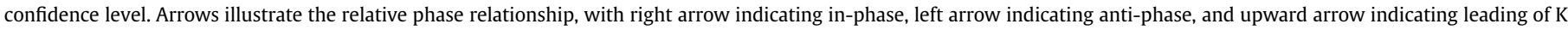
record by $90^{\circ}$.

provide a mechanistic understanding of the climate dynamics involved (Lu and Guo, 2013; Sun and An, 2005). Based on the occurrence of $H$. parviakitaensis and the absence of Dictyophimus bullatus, the estimated age at the bottom of $205.6 \mathrm{~m}$ (CSF-A)-long archive at Site U1422C is younger than 3.9-4.3 Ma. Prior to $2 \mathrm{Ma}$, we use two initial age controlling points, i.e. marine oxygen isotopic stage (MIS) G5 and M2, both relatively cold during the Pliocene glacial period (Lisiecki and Raymo, 2005), as well as five biostratigraphy tie points and one linear fitting tie point established using all the magneto-stratigraphy and bio-stratigraphy tie points at site U1422C (Fig. 2). After $2 \mathrm{Ma}$, our tuning is based on five magnetic-stratigraphy tie points at midpoint CSF-A (m) $33.5 \mathrm{~m}$, $41.5 \mathrm{~m}, 45.2 \mathrm{~m}, 77.5 \mathrm{~m}$ and $84.6 \mathrm{~m}$ (Fig. 2; Table 1). The $\mathrm{K}$ variations were virtually adjusted to global benthic $\delta^{18} \mathrm{O}$ stack (Lisiecki and Raymo, 2005) cycle-by-cycle, establishing a $3865 \mathrm{kyr}$ continuous age model. The final outcome of our tuning is presented in Fig. 5. The final tie-points are in Supplementary Table 2 and re-scaled $\mathrm{K}$ record is in Supplementary Table 3.

The excellent match between $\mathrm{K}$ variations and LR04 stack suggests that our tuned timescale is well constrained by the LR04 records and the validity of our tuning method (Fig. 5). The higher sedimentation rate between $90.52 \mathrm{~m}$ and $205.55 \mathrm{~m}$ might result from the frequent turbidite layers. A slightly lower Gamma Ray Attenuation density also suggests relatively higher diatom content during these periods, which may also contribute to the higher sedimentation rate at this interval (Expedition 346 Scientists, 2014). Sedimentation rates confirm that our $20-\mathrm{cm}$ sampling resolution ( $3.5 \mathrm{kyr})$ is high enough to fully resolve variations associated with variations in the obliquity and precession of Earth's rotational axis. The filtered 21- and 41- and 100-kyr components between LR0 4 and $\mathrm{K}$ data exhibit similar amplitude modulation (Fig. 6). The high coherence in the cross-spectral analysis suggested that LR0 4 and K data agree well since $\sim 4 \mathrm{Ma}$ (Fig. 7). The shift of dominant periodicity from $\sim 41 \mathrm{kyr}$ to $\sim 100 \mathrm{kyr}$ at $\sim 1$ Ma was observed in the benthic LR0 $4 \delta^{18} \mathrm{O}$ data as well as in our $\mathrm{K}$ record, known as the mid-Pleistocene transition (MPT) and detected in numerous marine and continental climate records (Clark et al., 2006) (Fig. 8). Overall, these lines of evidences support the good alignment of the K content at site U1422C to the LR04 stack.

Our age model allows refinements of the age control points established by magneto-stratigraphy and microfossils biostratigraphy at site U1422C (Expedition 346 Scientists, 2014). After tuning, we report slight age deviations of magnetic reversal boundaries between our estimated ages and the ages in Shackleton (1995) for the Top Jaramillo, Bottom Jaramillo, Top Olduvai as well as Bottom Olduvai boundaries (Fig. 5; Table 1). A large age offset (39 kyr) at the Brunhes/Matuyama (B/M) boundary between the age at midpoint of the $\mathrm{B} / \mathrm{M}$ depth interval in our age model and the age in S1995 model was observed. However, the depth uncertainty $(0.83 \mathrm{~m}, \mathrm{CSF}-\mathrm{A})$ at the $\mathrm{B} / \mathrm{M}$ boundary could yield an age interval from $0.783 \mathrm{Ma}$ to $0.843 \mathrm{Ma}$ in our age model and therefore the age at the $\mathrm{B} / \mathrm{M}$ boundary is within acceptable limit (Fig. 5; Table 1). A generally large age offset between our age model and the age model identified by the microfossils bio-events in preliminary report is expected, as nanofossil age model has large depth uncertainties (Fig. 5; Table 2). The differences might thus be attributed to uncertainty in the depth domain, as to where exactly these datums occur. Indeed, these events were identified only using corecatcher samples on DV JOIEDS Resolution. The microfossils assemblage reworking might account for the offset between our age model and the microfossils bio-events age model. For example, reworked Neodenticula kamtschatica (diatom specie) valves were found in Samples at Site U1422C, which also was noted at Ocean Drilling Program (ODP) Site 795 (Koizumi, 1992), the closest location to Site U1422 (Fig. 1). 

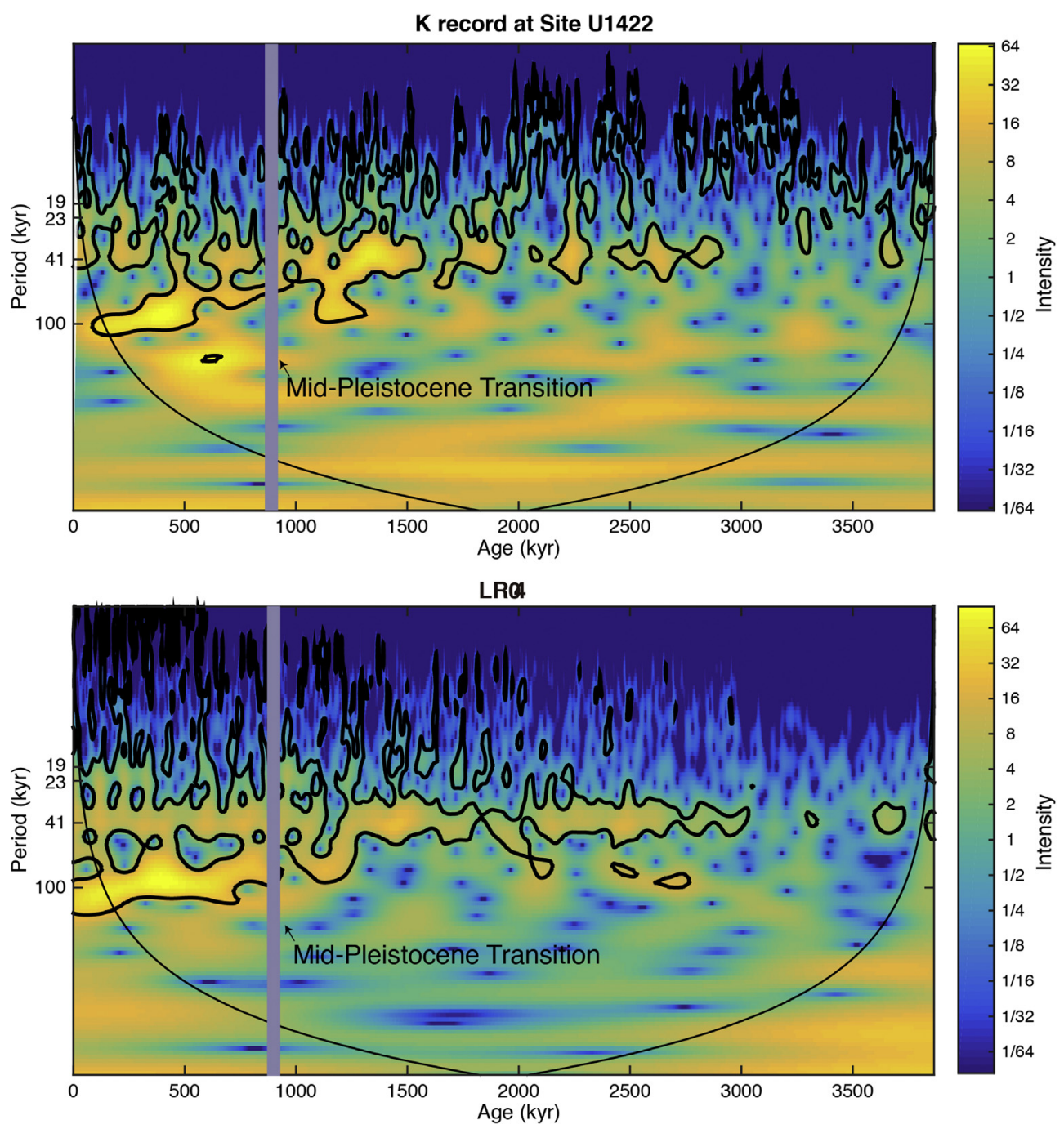

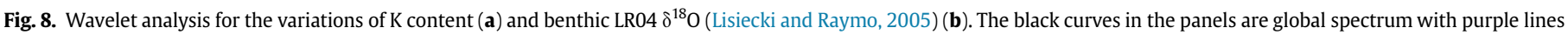

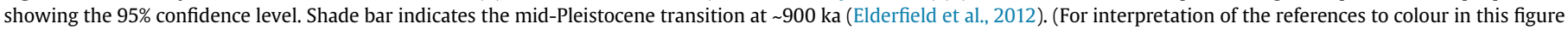
legend, the reader is referred to the Web version of this article.)

\section{Asian dust variability over the past $\sim 3.9 \mathrm{Ma}$}

Over the past $\sim 3.9 \mathrm{Ma}$, distinct $\mathrm{K}$ records fluctuations occurred over the glacial-interglacial timescales, especially since $\sim 3$ Ma. These fluctuations were superimposed on a gradual long-term increasing trend (Fig. 5). The long-term increase of $\mathrm{K}$ record at site U1422C in the Sea of Japan demonstrates a long-term aridity history of the Asian interior. This increasing trend coincided with the growth of North Hemisphere ice sheets revealed by the benthic $\delta^{18} \mathrm{O}$ stack (Lisiecki and Raymo, 2005) (Fig. 5).

We propose that Asian interior aridity is linked to the development of Northern Hemisphere ice sheets at both tectonic and orbital timescale since $\sim 3.9$ Ma. Global cooling may have controlled the stepwise Asian drying by reducing the amount of water vapor held in the atmosphere and increase the arid continental surface area (Lu and Guo, 2013). Uplift of Tibetan Plateau had a profound influence on the aridity of central Asia by blocking the input moisture from the Indian Ocean to the interior of continental Asia (Liu et al., 2014; Rea et al., 1998). The change in depositional facies and increase in sedimentation rate indicated that the uplift of Qilian Mountain, northeast Tibetan Plateau occurred at about 3.5-4.5 Ma (Zheng et al., 2000). The stepwise accelerated uplift of NE Tibetan
Plateau has also been suggested at $3.6 \mathrm{Ma}, 1.2 \mathrm{Ma}$ and $0.15 \mathrm{Ma}$, respectively (Li et al., 2014). However, sedimentological and thermochronology evidence reveals that the northeastern Tibetan Plateau experienced a phase of upward and/or outward growth during the Late Miocene (Zheng et al., 2006). The timing and history of Tibetan uplift is still under debate (Molnar and Tapponnier, 1975; Wang et al., 2011). The effect of retreat of the Paratethys on the aridity of Asian interior would not be expected in such a recent time period, as paleographic reconstructions suggested that the Paratethys had almost retreated from Central Asia by the middle Miocene ( 15 Ma) (Popova et al., 2004). This is supported by the multiple paleoclimatic proxies from Central Asia, suggesting that the retreat of the Paratethys played an minor important role in promoting the inner Asia's drying since the late Miocene (Miao et al., 2012). Nevertheless, the excellent cycle-per-cycle positive correlation between the K content and LR04 stack curve suggest the global ice volume might be the primary driver for the aridification of Asian interior at least since the early Pliocene.

\section{Conclusions}

The variations in the concentration of $\mathrm{K}$ retrieved from the 
205 m-long continuous sedimentary archive of IODP Site U1422 drilled in northern Sea of Japan contain a clear imprint of astronomical climate forcing, allowing for the development of spanning the last $\sim 3.9 \mathrm{Ma}$. The tuning assumes that $\mathrm{K}$ content is an indicator of relative contribution of Asian dust, reflecting the aridification history of the central Asian interior. K concentrations of U1422 sediments are higher during glacials. The cycle-by-cycle positive correlation between the K content and LR04 suggest the global ice volume was the primary driver for the intensification of aridification of Asian interior during the Plio-Pleistocene. The uplift of Tibetan Plateau might play a secondary role. The high-resolution orbital timescale age control at site U1422 would provide a platform for generating other proxy's work, allowing it to be a potentially ideal target for the ongoing research about Asian monsoon and paleoclimate change in the Sea of Japan.

\section{Acknowledgements}

We acknowledge the IODP Expedition 346 Shipboard scientific party, crew, and technical staff of DV JOIDES Resolution for recovering the samples and measuring the shipboard data. We sincerely appreciate the constructive comments and suggestions from anonymous reviewers that have greatly improved the manuscript. We are grateful to Prof. Sumin Wang for the constructive suggestions on this paper. This work was financially supported by the National Natural Science Foundation of China (Grant No. 41702191 and 41430530). DDV acknowledges financial support by the European Research Council (Consolidator Grant EarthSequencing, 617462) and the Deutsche Forschungsgemeinschaft (Project VL 96/ 1-1 to D.D.V. Grant No. 319497259). Wenfang Zhang was also supported by the Scientific Research Foundation of Nanjing Institute of Geography and Limnology (NIGLAS), Chinese Academy of Sciences (Grant No. Y7SL011001).

\section{Appendix A. Supplementary data}

Supplementary data related to this article can be found at https://doi.org/10.1016/j.quascirev.2018.03.004.

\section{References}

An, Z., Kutzbach, J.E., Prell, W.L., Porter, S.C., 2001. Evolution of Asian monsoons and phased uplift of the Himalayan Tibetan plateau since Late Miocene times. Nature 411, 62-66.

Ao, H., Dekkers, M.J., Qin, L., Xiao, G.Q., 2011. An updated astronomical timescale for the Plio-Pleistocene deposits from South China Sea and new insights into Asian monsoon evolution. Quat. Sci. Rev. 30, 1560-1575.

Biscaye, P.E., 1965. Mineralogy and sedimentation of recent deep-sea clay in the Atlantic Ocean and adjacent seas and oceans. Geol. Soc. Am. Bull. 76, 803-832.

Cande, S.C., Kent, D.V., 1995. Revised calibration of the geomagnetic polarity timescale for the Late Cretaceous and Cenozoic. J. Geophys. Res. 100, 6093.

Chamley, H., 1989. Clay Sedimentology. Springer-Verlag, Berlin.

Clark, P.U., Archer, D., Pollard, D., Blum, J.D., Rial, J.A., Brovkin, V., Mix, A.C., Pisias, N.G., Roy, M., 2006. The middle Pleistocene transition: characteristics. mechanisms, and implications for long-term changes in atmospheric PCO2. Quat. Sci. Rev. 25, 3150-3184.

Clemens, S.C., Murray, D.W., Prell, W.L., 1996. Nonstationary phase of the pliopleistocene Asian monsoon. Science 274, 943-948.

De Vleeschouwer, D., Dunlea, A.G., Auer, G., Anderson, C.H., Brumsack, H., de Loach, A., Gurnis, M., Huh, Y., Ishiwa, T., Jang, K., Kominz, M.A., März, C., Schnetger, B., Murray, R.W., Pälike, H., 2017a. Quantifying K, U, and Th contents of marine sediments using shipboard natural gamma radiation spectra measured on DV JOIDES Resolution. Geochem. Geophys. Geosyst. 18, 1053-1064.

De Vleeschouwer, D., Vahlenkamp, M., Crucifix, M., Pälike, H., 2017b. Alternating Southern and Northern Hemisphere climate response to astronomical forcing during the past 35 m.y. Geology 45, 375-378.

Ding, Z.L., Derbyshire, E., Yang, S.L., Yu, Z.W., Xiong, S.F., Liu, T.S., 2002. Stacked 2.6Ma grain size record from the Chinese loess based on five sections and correlation with the deep-sea $\delta^{18} \mathrm{O}$ record. Paleoceanography 17, 5-1-5-21.

Dunlea, A.G., Murray, R.W., Harris, R.N., Vasiliev, M.A., Evans, H., Spivack, A.J., D'Hondt, S., 2013. Assessment and use of NGR instrumentation on the JOIDES Resolution to quantify $\mathrm{U}, \mathrm{Th}$, and $\mathrm{K}$ concentrations in marine sediment. Sci.

\section{Drill. 15, 57-63.}

Ehrenberg, S.N., Svånå, T.A., 2001. Use of spectral gamma-ray signature to interpret stratigraphic surfaces in carbonate strata: An example from the finnmark carbonate platform (Carboniferous-Permian), Barents sea. AAPG Bull. 85, 295-308.

Elderfield, H., Ferretti, P., Greaves, M., Crowhurst, S., McCave, I.N., Hodell, D. Piotrowski, A.M., 2012. Evolution of ocean temperature and ice volume through the mid-pleistocene climate transition. Science 337, 704-709.

Engelbrecht, J.P., Derbyshire, E., 2010. Airborne mineral dust. Elements 6, 241-246.

Expedition 346 Scientists, 2014. Asian Monsoon: Onset and Evolution of Millennialscale Variability of Asian Monsoon and its Possible Relation with Himalaya and Tibetan Plateau Uplift. IODP Prel. Rept. 346.

Ferrat, M., Weiss, D.J., Strekopytov, S., Dong, S.F., Chen, H.Y., Najorka, J., Sun, Y.B., Gupta, S., Tada, R., Sinha, R., 2011. Improved provenance tracing of Asian dust sources using rare earth elements and selected trace elements for palaeomonsoon studies on the eastern Tibetan Plateau. Geochem. Cosmochim. Acta 75, 6374-6399.

Gilmore, G., 2011. Practical Gamma-Ray Spectroscopy. John Wiley, Warrington, U. K.

Grinsted, A., Moore, J.C., Jevrejeva, S., 2004. Application of the cross wavelet transform and wavelet coherence to geophysical time series. Nonlinear Process Geophys. 11, 561-566.

Hovan, S.A., Rea, D.K., Pisias, N.G., Shackleton, N.J., 1989. A direct link between the China loess and marine Delta-O-18 records - Aeolian flux to the north pacific Nature 340, 296-298.

Janecek, T.R., 1985. Eolian sedimentation in the northwest pacific-ocean - a preliminary examination of the data from deep-sea drilling project Site 576 and Site 578. Init. Rept. 86, 589-603.

Janecek, T.R. Rea, D.K., 1983. Eolian deposition in the northeast pacific-ocean cenozoic history of Atmospheric circulation. Geol. Soc. Am. Bull. 94, 730-738.

Janecek, T.R., Rea, D.K., 1985. Quaternary fluctuations in the Northern Hemisphere trade winds and westerlies. Quat. Res. 24, 150-163.

Jeong, G.Y., Kim, J.Y., Seo, J., Kim, G.M., Jin, H.C., Chun, Y., 2014. Long-range transport of giant particles in Asian dust identified by physical, mineralogical, and meteorological analysis. Atmos. Chem. Phys. 14, 505-521.

Kanayama, S., Yabuki, S., Zeng, F.J., Liu, M.Z., Shen, Z.B., Liu, L.C., Yanagisawa, F., Abe, O., 2005. Size-dependent geochemical characteristics of Asian dust - Sr and $\mathrm{Nd}$ isotope compositions as tracers for source identification. J. Meteorol. Soc. Jpn. 83A, 107-120.

Koizumi, I., 1992, 127128_1. Diatom Biostratigraphy of the Japan Sea: Leg, vol 127.

Li, J., Fang, X., Song, C., Pan, B., Ma, Y., Yan, M., 2014. Late Miocene-Quaternary rapid stepwise uplift of the NE Tibetan Plateau and its effects on climatic and environmental changes. Quat. Res. 81, 400-423.

Lisiecki, L.E., Raymo, M.E., 2005. A Pliocene-Pleistocene stack of 57 globally distributed benthic $\delta^{18} \mathrm{O}$ records. Paleoceanography 20, PA1003.

Liu, W., Liu, Z., An, Z., Sun, J., Chang, H., Wang, N., Dong, J., Wang, H., 2014. Late Miocene episodic lakes in the arid Tarim Basin, western China. Proc. Natl. Acad. Sci. U.S.A. 111, 16292-16296.

Lu, H., Guo, Z., 2013. Evolution of the monsoon and dry climate in East Asia during late Cenozoic: A review. Sci. China Earth Sci. 57, 70-79.

Martinez-Garcia, A., Rosell-Mele, A., Jaccard, S.L., Geibert, W., Sigman, D.M., Haug, G.H., 2011. Southern Ocean dust-climate coupling over the past four million years. Nature 476, 312-U141.

Miao, Y., Herrmann, M., Wu, F., Yan, X., Yang, S., 2012. What controlled mid-late Miocene long-term aridification in central Asia? - global cooling or Tibetan plateau uplift: A review. Earth Sci. Rev. 112, 155-172.

Molnar, P. Tapponnier, P. 1975. Cenozoic Tectonics of Asia: effects of a Continental Collision: features of recent continental tectonics in Asia can be interpreted as results of the India-Eurasia collision. Science 189, 419-426.

Nagashima, K., Tada, R., Tani, A., Sun, Y., Isozaki, Y., Toyoda, S., Hasegawa, H., 2011. Millennial-scale oscillations of the westerly jet path during the last glacial period. J. Asian Earth Sci. 40, 1214-1220.

Nagashima, K., Tada, R., Tani, A., Toyoda, S., Sun, Y., Isozaki, Y., 2007. Contribution of aeolian dust in Japan Sea sediments estimated from ESR signal intensity and crystallinity of quartz. Geochem. Geophys. Geosyst. 8. Q02Q04.

Nagashima, K., Tada, R., Toyoda, S., 2013. Westerly jet-East Asian summer monsoon connection during the Holocene. Geochem. Geophys. Geosyst. 14, 5041-5053.

Popova, S.V., Rögl, F., Rozanov, A.Y., Steininger, F.F., Shcherba, I.G., Kovac, M., 2004 Lithological-paleogeographic Maps of Paratethys-10 Maps Late Eocene to Pliocene (CFS, Cour. Forsch.inst. Senckenb).

Pye, K., 1987. Front Matter A2-PYE, KENNETH, Aeolian Dust and Dust Deposits. Academic Press.

Ramstein, G., Fluteau, F., Besse, J., Joussaume, S., 1997. Effect of orogeny, plate motion and land sea distribution on Eurasian climate change over the past 30 million years. Nature 386, 788-795.

Rea, D.K., Basov, I.A., Janecek, T.R., Palmer-Julson, A., 1993. Proceedings of the ocean drilling Program. Init. Rep. 145.

Rea, D.K., Snoeckx, H., Joseph, L.H, 1998. Late Cenozoic eolian deposition in the North Pacific: Asian drying, Tibetan uplift, and cooling of the northern hemisphere. Paleoceanography 13, 215-224.

Serno, S., Winckler, G., Anderson, R.F., Maier, E., Ren, H.J., Gersonde, R., Haug, G.H. 2015. Comparing dust flux records from the Subarctic North Pacific and Greenland: implications for atmospheric transport to Greenland and for the application of dust as a chronostratigraphic tool. Paleoceanography 30 , 583-600.

Shackleton, N.J., 1995. Pliocene stable isotope stratigraphy of site 846. Proc. ODP, Sci. Results 138, 337-355. 
Shao, Y., Wyrwoll, K.-H., Chappell, A., Huang, J., Lin, Z., McTainsh, G.H., Mikami, M., Tanaka, T.Y., Wang, X., Yoon, S., 2011. Dust cycle: An emerging core theme in Earth system science. Aeolian Res. 2, 181-204.

Shen, X., Wan, S., France-Lanord, C., Clift, P.D., Tada, R., Révillon, S., Shi, X., Zhao, D. Liu, Y., Yin, X., Song, Z., Li, A., 2017. History of Asian eolian input to the Sea of Japan since 15 Ma: links to Tibetan uplift or global cooling? Earth Planet Sci. Lett. 474, 296-308.

Shen, Z., Li, X., Cao, J., Caquineau, S., Wang, Y., Zhang, X., 2005. Characteristics of clay minerals in asian dust and their environmental significance. China Particuol. 3 , $260-264$.

Sun, J.M., Zhang, M.Y., Liu, T.S., 2001. Spatial and temporal characteristics of dust storms in China and its surrounding regions, 1960-1999: relations to source area and climate. J. Geophys. Res. Atmos. 106, 10325-10333.

Sun, Y., An, Z., 2005. Late Pliocene-Pleistocene changes in mass accumulation rates of eolian deposits on the central Chinese Loess Plateau. J. Geophys. Res. 110. D23101.

Sun, Y., Clemens, S.C., An, Z., Yu, Z., 2006. Astronomical timescale and palaeoclimatic implication of stacked 3.6-Myr monsoon records from the Chinese Loess Plateau. Quat. Sci. Rev. 25, 33-48.

Tiedemann, R., Sarnthein, M., Shackleton, N.J., 1994. Astronomic timescale for the Pliocene atlantic $\delta 180$ and dust flux records of ocean drilling Program site 659 Paleoceanography 9, 619-638.
Torrence, C., Compo, G.P., 1998. A practical guide to wavelet Analysis. Bull. Am. Meteorol. Soc. 79, 61-78.

Vasiliev, M.A., Blum, P., Chubarian, G., Olsen, R., Bennight, C., Cobine, T., Fackler, D., Hastedt, M., Houpt, D., Mateo, Z., Vasilieva, Y.B., 2011. A new natural gamma radiation measurement system for marine sediment and rock analysis. J. Appl. Geophys. 75, 455-463.

Wang, G.C., Cao, K., Zhang, K.X., Wang, A., Liu, C., Meng, Y.N., Xu, Y.D., 2011. Spatiotemporal framework of tectonic uplift stages of the Tibetan Plateau in Cenozoic. Sci. China Earth Sci. 54, 29-44.

Winckler, G., Anderson, R.F., Fleisher, M.Q., Mcgee, D., Mahowald, N., 2008. Covariant glacial-interglacial dust fluxes in the equatorial Pacific and Antarctica. Science 320, 93-96.

Yu, Z.W., Ding, Z.L., 1998. An automatic orbital tuning method for paleoclimate records. Geophys. Res. Lett. 25, 4525-4528.

Zhang, W., Chen, J., Ji, J., Li, G., 2016. Evolving flux of Asian dust in the north Pacific ocean since the late oligocene. Aeolian Res. 23, 11-20.

Zheng, D., Zhang, P.-Z., Wan, J., Yuan, D., Li, C., Yin, G., Zhang, G., Wang, Z., Min, W. Chen, J., 2006. Rapid exhumation at $\sim 8$ Ma on the Liupan Shan thrust fault from apatite fission-track thermochronology: implications for growth of the northeastern Tibetan Plateau margin. Earth Planet Sci. Lett. 248, 198-208.

Zheng, H., Powell, C.M., An, Z., Zhou, J., Dong, G., 2000. Pliocene uplift of the northern Tibetan Plateau. Geology 28, 715-718. 